\title{
KARAKTERISTIK CEBAKAN TIMAH PRIMER DI DAERAH PARIT TEBU, KABUPATEN BELITUNG TIMUR, PROVINSI KEPULAUAN BANGKA BELITUNG
}

\section{CHARACTERISTIC OF THE PRIMARY TIN DEPOSITS IN PARIT TEBU AREA, BELITUNG TIMUR REGENCY, BANGKA BELITUNG ISLANDS PROVINCE}

\author{
Bambang Pardiarto \\ Pusat Sumber Daya Mineral Batubara dan Panas Bumi \\ Jalan Soekarno Hatta No. 444, Bandung \\ b.pardiarto@yahoo.com
}

\begin{abstract}
ABSTRAK
Endapan timah sekunder banyak tersebar dan ditambang di wilayah Kabupaten Belitung Timur namun belum jelas dari mana sumber potensial cebakan timah primernya. Survei geofisika dengan metoda polarisasi terimbas (IP) dan magnetik di daerah tersebut menghasilkan beberapa anomali mengindikasikan adanya terobosan batuan granit yang diduga sebagai sumber cebakan timah. Hasil penelitian terbaru dengan metoda pengeboran inti dan analisisis laboratorium yang meliputi Atomic Absorption Spectrometry (AAS), X-Ray Fluorescence (XRF), petrografi dan mineragrafi menunjukkan mineralisasi timah primer mempunyai bentuk cebakan berupa urat-urat halus dan sebagian tersebar dalam masa batuan. Mineralisasi terjebak dalam batupasir kuarsa arenit dan metabatulempung akibat diterobos oleh granit aplitik. Mineralisasi timah dicirikan oleh hadirnya kasiterit yang berasosiasi dengan realgar, molibdenit dan beberapa mineral sulfida seperti pirit, sfalerit, galena dan arsenopirit dalam mineral gangue kuarsa. Genesa cebakan diklasifikasikan sebagai tipe urat hidrotermal dengan kandungan kaya timah terkonsentrasi pada zona urat kuarsa yang terbreksikan.
\end{abstract}

Kata kunci: parit tebu, cebakan timah, kasiterit, realgar, molibdenit

\section{ABSTRACT}

Secondary tin deposits are widely ditributed and mined in Belitung Timur Regency however the potential source of primary tin deposit still unclear. Geophysical survey using induced polarization (IP) and magnetic method obtained some anomalies indicating granite intrusion which is inferred to be source of tin deposit. The recent research using core-drilling method and laboratory analysis including Atomic Absorption Spectrometry (AAS), X-Ray Fluorescence (XRF), petrography and mineragraphy shows the primary tin mineralisation has deposit form as veinlets and partly disseminated in the rock mass. Mineralisation are hosted by quartz-arenite sandstone and metaclaystone wich are intruded by aplitic granite. Tin mineralisation is characterised by presence of cassiterite associated with realgar, molibdenite dan some sulphide minerals such as pyrite, sphalerite, galena and arsenopyrite with gangue mineral of quartz. The genetic of deposit is classified as vein type with tin rich content is concentrated along zone of brecciated quartz vein.

Keywords: parit tebu, tin deposit, cassiterite, realgar, molibdenite

\section{PENDAHULUAN}

Endapan timah sekunder banyak tersebar dan ditambang oleh masyarakat maupun perusahaan diwilayah Belitung Timur, namun belum diketahui sumber potensial cebakan timah primernya. Hasil eksplorasi cebakan timah primer terdahulu di daerah Parit Tebu yang meliputi pemetaan geologi rinci dan survei polarisasi terimbas (IP) serta magnetik memperlihatkan adanya zona anomali geofisika. Hasil 


\section{MAKALAH ILMIAH}

interpretasi zona anomali ini berhubungan dengan keberadaan batuan granit yang diduga sebagai sumber cebakan timah primer (Aziz, dkk., 2014). Hal tersebut yang menjadi pertimbangan dilakukannya eksplorasi lanjutan di daerah ini dengan pengeboran uji geologi.

Lokasi penelitian berada di daerah Parit Tebu, Desa Batu Penyu, Kecamatan Gantung, Kabupaten Belitung Timur, Provinsi Kepulauan Bangka Belitung (Gambar 1). Penelitian ini dimaksudkan untuk mengetahui kondisi geologi bawah permukaan yang berkaitan dengan anomali geofisika dengan tujuan untuk mendapatkan gambaran batuan pembawa mineralisasi timah primer dan tipe cebakannya.

\section{METODA}

Penelitian ini menggunakan metoda pengeboran, pengamatan batuan inti bor, pemeriksaan laboratorium yang meliputi analisis kimia dengan metoda AAS (Mo, $\mathrm{Cu}, \mathrm{Pb}, \mathrm{Zn}, \mathrm{Au}, \mathrm{Sn}$ dan $\mathrm{Li}$ ), petrografi, mineragrafi dan XRF.

\section{GEOLOGI DAN GEOFISIKA}

\section{Geologi Regional}

Secara regional Pulau Belitung ditutupi oleh runtunan batuan metasedimen yang berumur dari Karbon hingga Perem. Runtunan ini dibedakan menjadi Formasi Kelapakampit, Formasi Tajam dan Formasi Siantu (Baharuddin, dkk., 1995). Runtunan batuan ini terdiri dari batupasir, serpih, batulempung dan rijang mempunyai kemiringan yang hampir tegak. Beberapa sisipan tipis berupa lava bantal, tuf dan batugamping dijumpai dalam runtunan batuan ini.

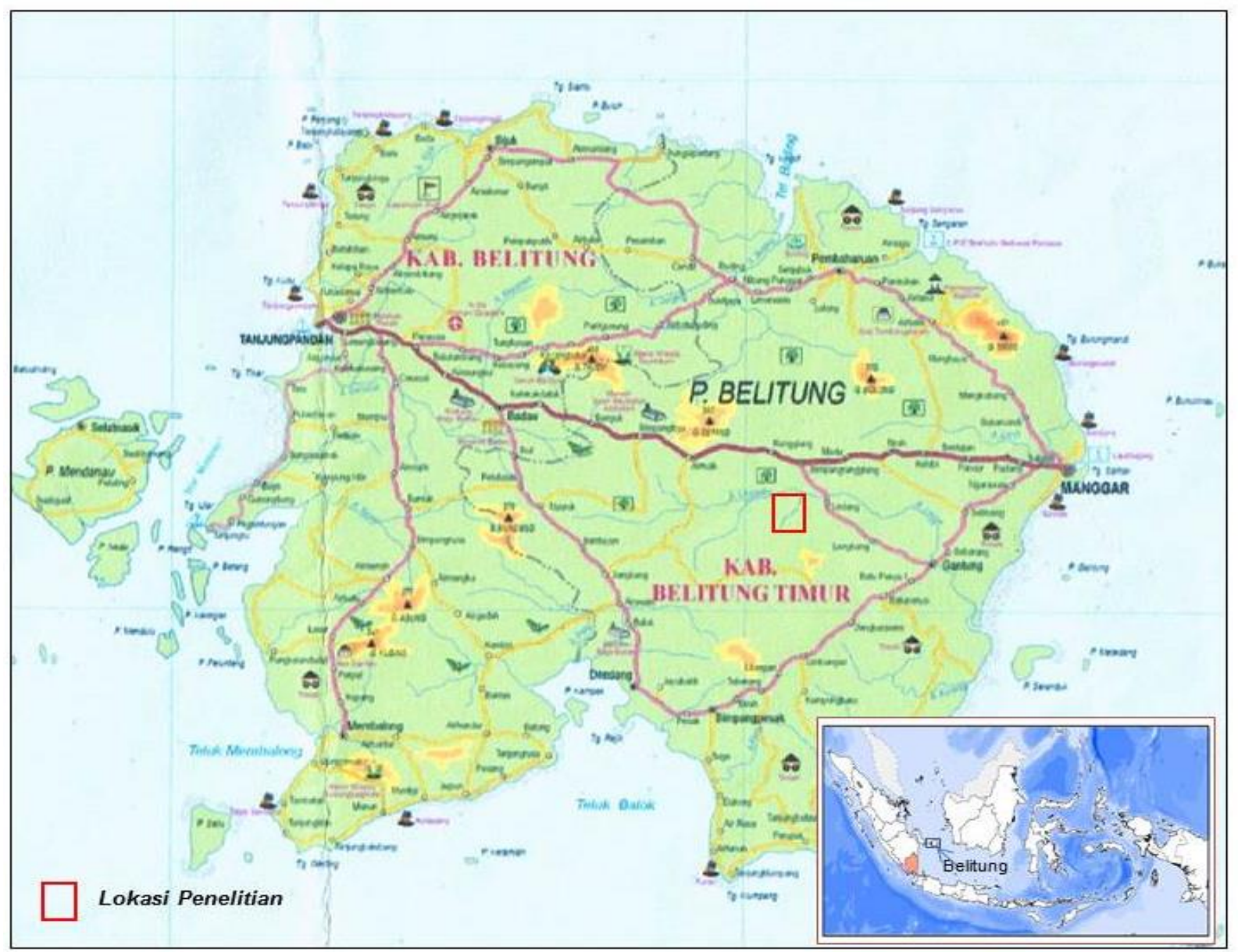

Gambar 1. Peta lokasi daerah penelitian. 
Arah umum jurus perlapisan batuan sedimen berkisar antara barat-timur hingga tenggara-baratlaut dengan sudut kemiringan lapisan subvertikal. Pergeseran akibat sesar menyebabkan terjadinya perubahan mencolok arah sudut kemiringan lapisan batuan dari selatan ke utara. Di samping itu runtunan batuan ini juga telah mengalami perlipatan kuat dengan arah timurlaut-baratdaya, utaraselatan dan baratlaut-tenggara. Pada zaman Trias runtunan batuan sedimen (Permo-Karbon) ini diterobos oleh batuan plutonik berupa gabro, granodiorit, adamelit, retas porfiri dan granit (Trias). Di Pulau Belitung terdapat beberapa jenis granit diantaranya Granit Burung Mandi, Granit Batubesi dan Granit Tanjung Pandan.

Pulau Belitung termasuk ke dalam jalur timah Indonesia yang memanjang dengan arah tenggara hingga barat laut menerus hingga ke Malaysia-Thailand dan Burma (Myanmar). Selain Pulau Belitung, Pulau Bangka, Pulau Singkep, Pulau Kundur, Pulau Karimun dan pulau-pulau kecilnya juga termasuk penghasil timah di Indonesia. Jalur timah ini menerus hingga ke Malaysia-Thailand dan Burma. Pulaupulau tersebut dikenal sebagai penghasil timah terbesar di dunia (Lehmann, 1990). Bijih timah yang dihasilkan berasal dari endapan placer. Terbentuknya timah di jalur timah Indonesia ini akibat terobosan batuan granit berumur Trias terhadap runtunan batuan sedimen yang lebih tua.

Di Pulau Belitung, timah terbentuk karena adanya terobosan granit yang dikenal dengan Granit Kelapakampit berumur Trias. Beberapa cebakan timah dijumpai di pulau ini meliputi Tambang Tikus, Tambang Kelapakampit, Tambang Parit Tebu, Tambang Batu Besi, dan lainnya (Schwartz, dkk., 1990)

\section{Geologi dan Geofisika Daerah Penelitian}

Satuan batuan yang mendominasi daerah penelitian terdiri atas batupasir kuarsa berselingan dengan batulempung dan batulanau termetakan yang diduga merupakan bagian dari Formasi Tajam berumur Permo-Karbon. Kemudian satuan batuan tersebut secara menjemari berhubungan dengan meta batupasir kuarsa/kuarsit, batusabak dan lempung tufaan yang merupakan bagian dari Formasi Kelapakampit yang juga berumur Permo-Karbon (Soepriadi, dkk., 2015). Jurus dan kemiringan lapisan batupasir yang kontak dengan batulempung berarah $\mathrm{N} 160^{\circ}$ s.d. $170^{\circ} \mathrm{E} / 15^{\circ}$ dan $\mathrm{N} 280^{\circ}$ s.d. $300^{\circ} \mathrm{E} / 45^{\circ}$ (Gambar 2a). Umumnya batuan ini telah mengalami pelapukan kuat yang membentuk endapan laterit limonitik mengandung mineral oksida besi.

Sebagian satuan batuan tersebut masih tampak segar dengan ubahan silika, pirit dan lempung serta setempat-setempat mengandung urat/urat halus kuarsa. Batuan terkekarkan kuat dan retakan yang terbentuk diisi oleh urat kuarsa tipis $(<7$ $\mathrm{mm}$ ) dan oksida besi/limonit yang saling berpotongan sebagaimana dijumpai di sekitar Bukit Klenteng. Endapan aluvial merupakan endapan termuda terdiri atas pasir, lanau dan lempung yang menutupi kedua satuan batuan tersebut dengan menempati pada lembah sungai.

Struktur geologi yang teramati berupa kekar-kekar dan patahan normal yang diperkirakan berarah hampir utara-selatan. Gejala patahan ini ditandai oleh adanya pola perubahan jurus dan kemiringan lapisan batupasir sebagaimana yang teramati di sekitar Bukit Klenteng. Selain itu kekar-kekar yang terbentuk umumnya terisi oleh oksida besi/limonit.

Indikasi mineralisasi berupa urat/urat halus kuarsa dengan tebal $1 \mathrm{~mm}$ s.d. 3 $\mathrm{cm}$, tidak beraturan dan saling berpotongan pada perselingan batupasir kuarsa dan meta batulempung. Mineral kasiterit teramati pada dua singkapan urat kuarsa dengan tebal $1 \mathrm{~cm}$ hingga $2,5 \mathrm{~cm}$, agak transparan, kristalin dan tekstur vugh dan comb, jurus dan kemiringan $\mathrm{N} 100^{\circ}$ $\mathrm{E} / 50^{\circ}$ dan $\mathrm{N} 65^{\circ} \mathrm{E} / 55^{\circ}$ seperti yang ditemukan di daerah Bukit Klenteng (Gambar 2b). 


\section{MAKALAH ILMIAH}
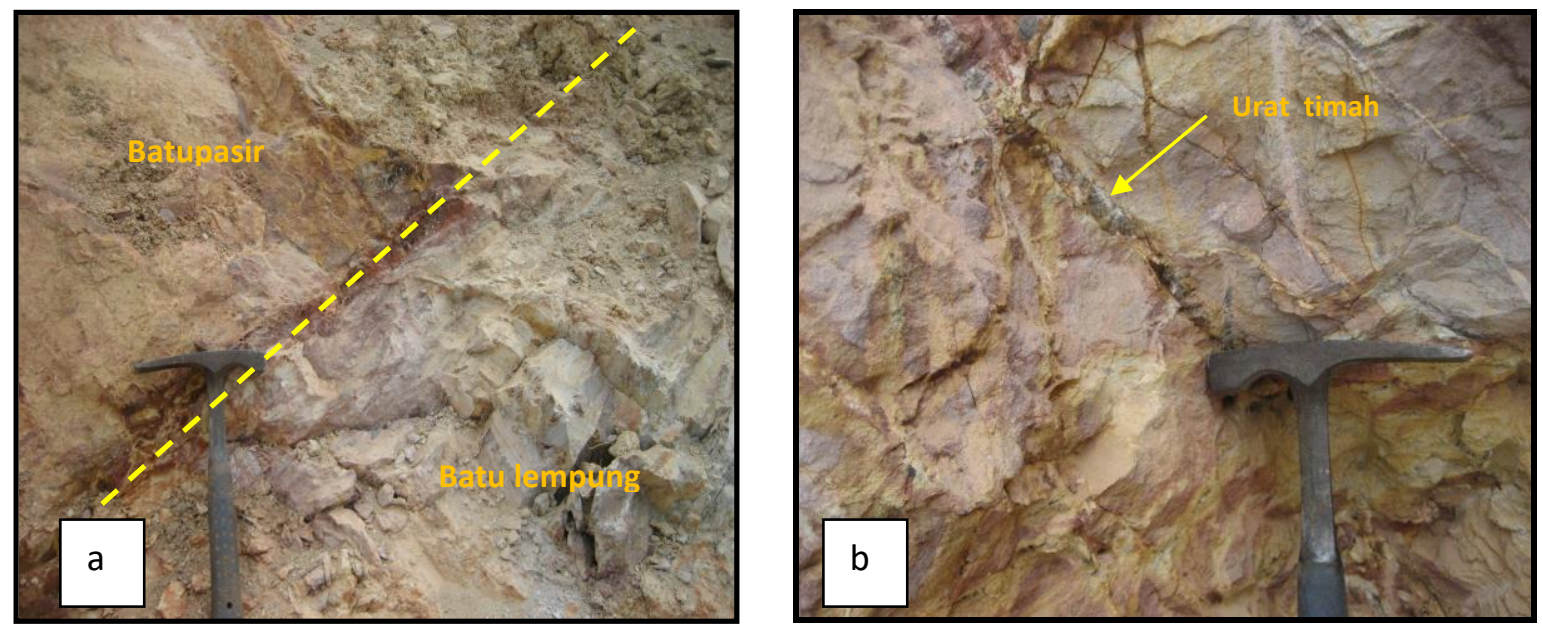

Gambar 2. (a) Singkapan kontak antara batupasir kuarsa dan batulempung dengan jurus dan kemiringan $\mathrm{N} 280^{\circ} \mathrm{E} / 45^{\circ}$ di daerah Bukit Klenteng. (b) Urat kuarsa tipis berarah $\mathrm{N} 100^{\circ}$

$\mathrm{E} / 50^{\circ}$ pada perselingan batupasir kuarsa dan meta batulempung mengandung mineral kasiterit di daerah Bukit Klenteng.

Selain itu hasil pelapukan bijih logam berupa gossan yang mengandung gutit, jarosit dan hematit juga ditemukan di sekitar daerah ini. Diduga terbentuknya gossan akibat dari proses pelapukan terhadap batuan termineralisasi dengan intensitas kuat urat-urat tipis dan kandungan besi yang tinggi sehingga memberikan warna merah dan kuning kecoklatan. Peta geologi daerah penelitian ditampilkan pada Gambar 3.

Hasil interpretasi dari lima lintasan geofisika polarisasi terimbas (IP) A sampai $\mathrm{E}$ dan magnetik menunjukkan adanya anomali tahanan jenis dan chargeability. Berdasarkan hasil interpretasi geofisika tersebut dilakukan pengeboran LB.01, LB.02, dan LB.03.

Titik pengeboran LB.01 berada pada lintasan $C$ geofisika IP dengan ketinggian $38 \mathrm{~m}$ di atas permukaan laut merupakan lokasi pengeboran yang berjarak $\pm 700 \mathrm{~m}$ arah baratlaut dari titik pengeboran LB.02. Kondisi geologi permukaan ditempati oleh satuan batuan malihan berupa perselingan batusabak, batulumpur serpih, batulanau, tufa, rijang yang merupakan bagian dari Formasi Kelapakampit berumur PermoKarbon. Mineralisasi di sekitar titik pengeboran ini adalah hydrous iron oxide (gutit).
Interpretasi lintasan C geofisika IP memperlihatkan pola yang cenderung merendah ke arah timurlaut (Gambar 4). $\mathrm{Di}$ bagian atas dekat permukaan didominasi oleh nilai tahanan jenis dan chargeability yang rendah. Nilai tahanan jenis rendah diperkirakan berasosiasi dengan batuan sedimen. Nilai tahanan jenis tinggi di sebelah baratdaya diperkirakan berasosiasi dengan batuan yang bersifat resistif. Hasil interpretasi mulai pada kedalaman $69 \mathrm{~m}, 101 \mathrm{~m}$, $136 \mathrm{~m}, 100 \mathrm{~m}$ dan $175 \mathrm{~m}$ diduga sebagai batuan granit pembawa timah (Azis, dkk., 2014).

Titik pengeboran LB.02 terletak pada lintasan E geofisika IP pada ketinggian 32 $\mathrm{m}$ di atas permukaan laut. Kondisi geologi permukaan ditempati oleh satuan batuan malihan terdiri perselingan batusabak, batulumpur, serpih dan batulanau. Mineralisasi yang ditemukan berupa oksida besi dan hematit. Hasil analisis kimia conto batuan menunjukkan kandungan 20 ppm Li dan 400 ppm Sn (Soepriadi, dkk., 2014).

Interpretasi lintasan E geofisika IP menunjukkan sebaran tahanan jenis dan chargeability didominasi oleh nilai tahanan jenis dan chargeability yang rendah (Gambar 5). Nilai tahanan jenis rendah ini mengindikasikan batuan yang bersifat 


\section{MAKALAH ILMIAH}

konduktif, yang diduga berupa batuan sedimen. Nilai chargeability rendah mengindikasikan sedikitnya kandungan mineral sulfida yang dapat menyimpan arus. Di bagian bawah sebelah baratdaya terlihat ada anomali berupa nilai tahanan jenis tinggi (>10.000 Ohm.m) yang menunjukkan keberadaan batuan granit (Azis, dkk., 2014).

Titik pengeboran LB.03 terletak pada lintasan E geofisika IP berjarak sekitar $1.200 \mathrm{~m}$ ke arah timurlaut dari titik pengeboran LB.02. Kondisi geologi permukaan ditempati oleh satuan endapan aluvial yang didominasi oleh lempung dan lanau. Titik pengeboran LB.03 yang didukung dengan analisis anomali magnit menunjukkan kesinambungan ke arah atas (upward continuation) dengan ketinggian bervariasi dari $25 \mathrm{~m}$ hingga 100 m (Gambar 6) (Azis, dkk., 2014).

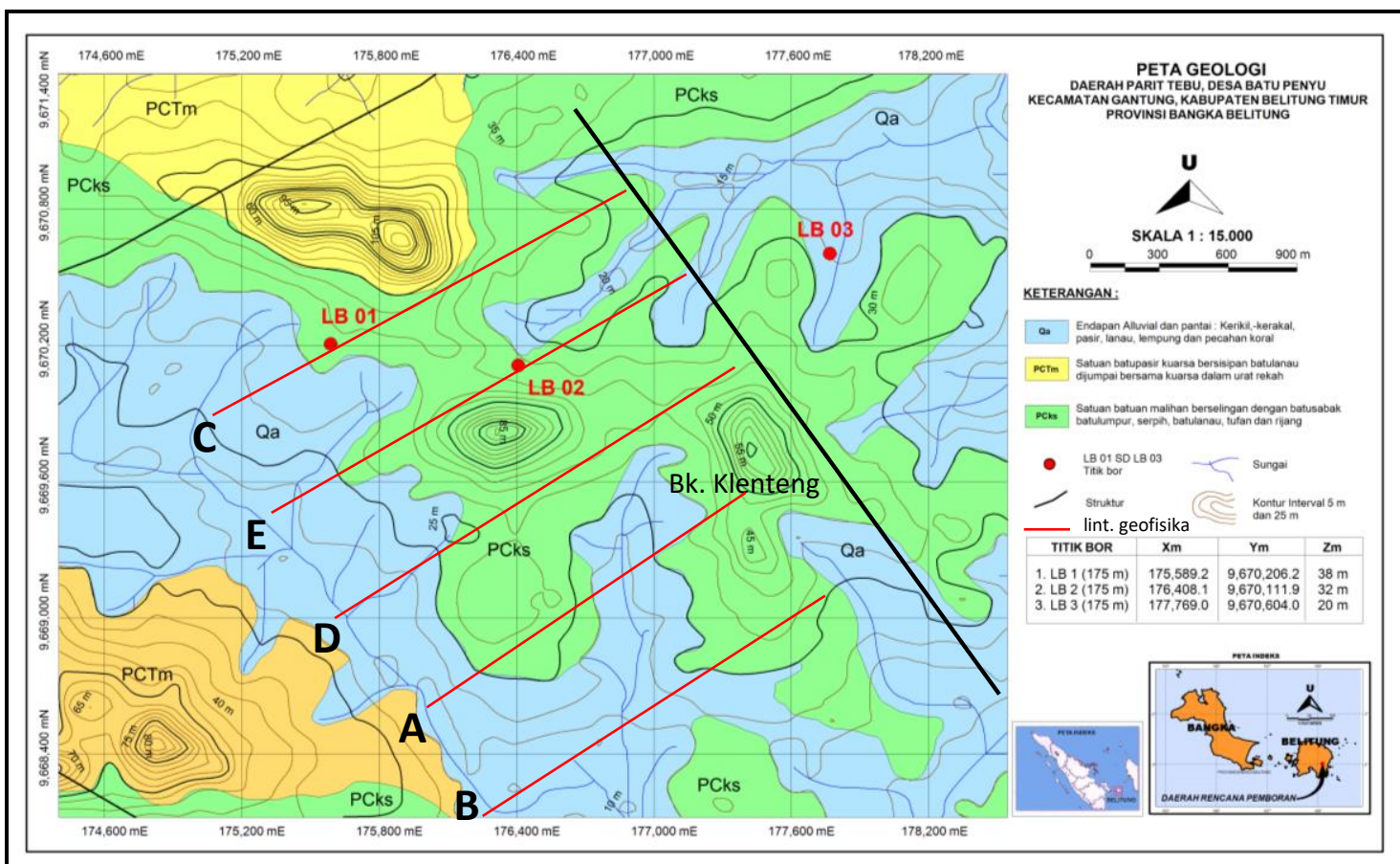

Gambar 3. Peta geologi, lintasan geofisika (A-E) dan lokasi titik pengeboran (LB.01, LB.02, LB.03) daerah Parit Tebu, Kecamatan Gantung, Kabupaten Belitung Timur, Provinsi Kepulauan Bangka Belitung (Soepriadi, dkk., 2015).

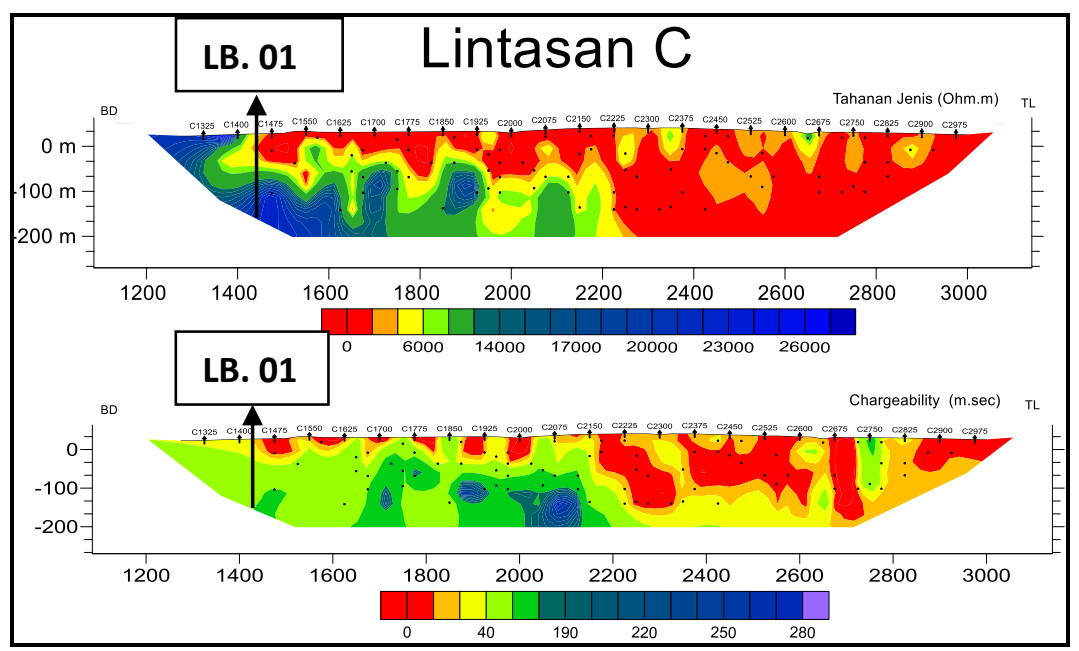

Gambar 4. Peta hasil penafsiran geofisika lintasan C daerah Parit Tebu Titik Bor LB.01 (Azis, dkk., 2014). 


\section{MAKALAH ILMIAH}

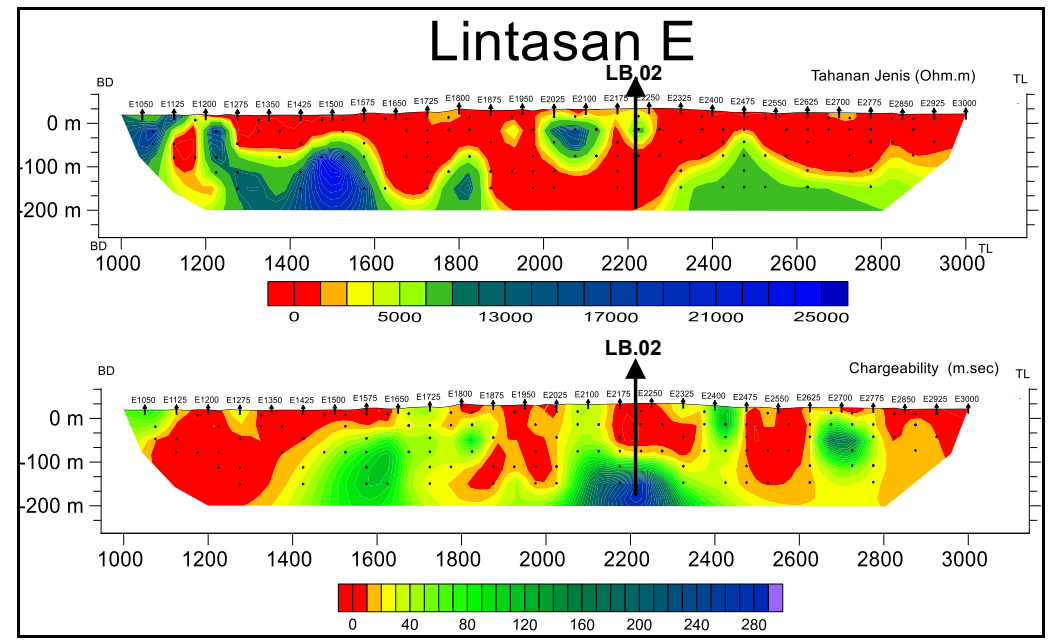

Gambar 5. Peta hasil penafsiran geofisika lintasan E daerah Parit Tebu lokasi titik bor LB.02 (Azis, dkk., 2014)
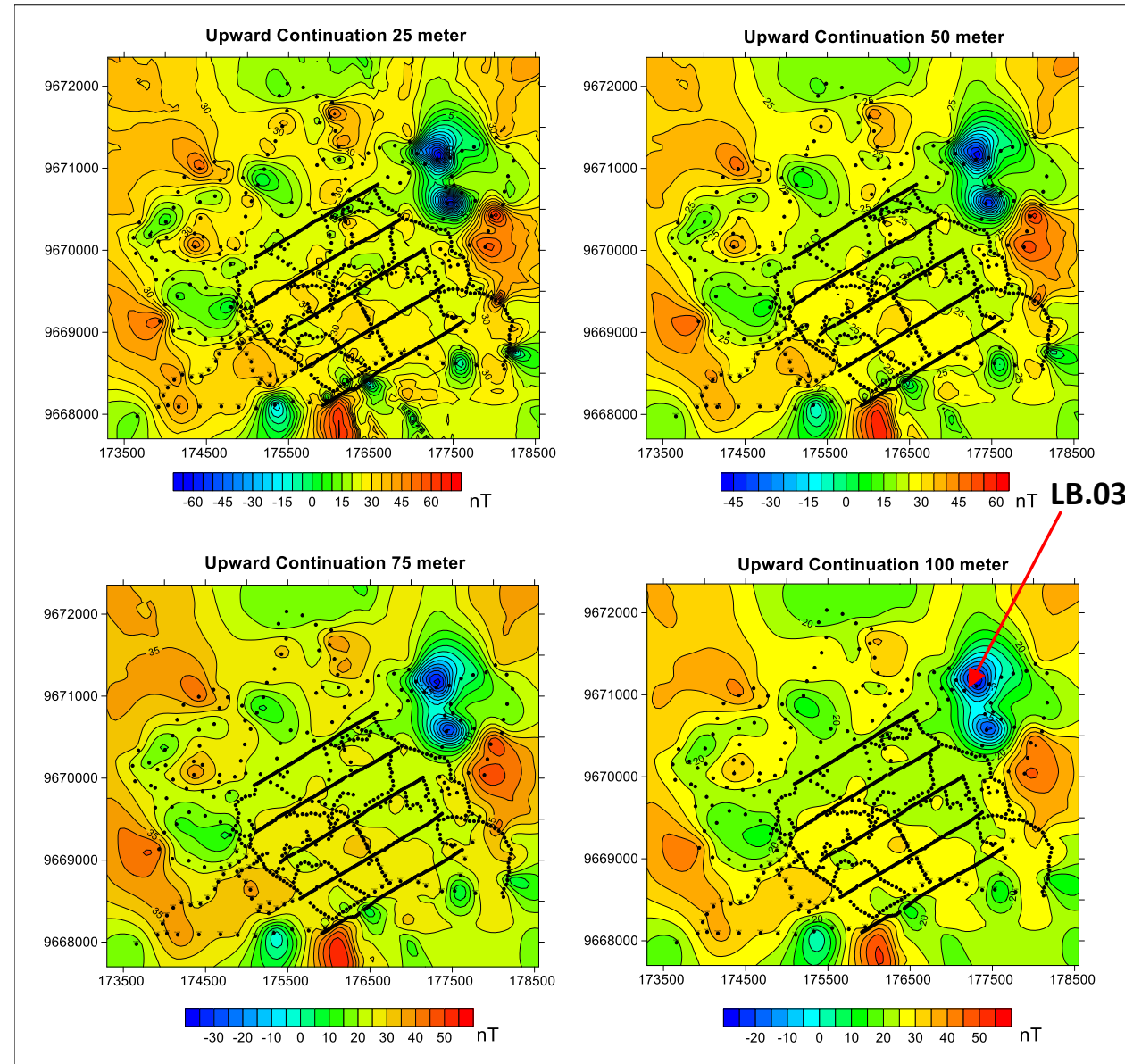

Gambar 6. Lokasi titik pengeboran LB.03 dan peta anomali magnetik memperlihatkan kesinambungan ke atas (upward continuation) dengan ketinggian yang bervariasi, dari 25 meter hingga 100 meter (Azis, dkk., 2014)

\section{HASIL DAN ANALISIS}

Pengamatan batuan dalam inti bor yang terdapat di daerah ini terutama LB.01 dan
LB.02 pada bagian atas merupakan endapan aluvial. Sedangkan pada LB.03 bagian atas ditutupi oleh endapan gossan (Soepriadi, dkk., 2015). Berikut 
rangkuman kondisi geologi bawah permukaan dan mineralisasi pada tiga lubang bor dari permukaan hingga bagian paling bawah.

\section{Titik Pengeboran LB.01}

Pada kedalaman $00,00 \mathrm{~m}$ s.d. $10,50 \mathrm{~m}$ merupakan endapan aluvial yang terdiri atas pasir, pasir lempungan, lempung, berwarna putih kekuningan sampai kecoklatan dan bersifat lempungan dan limonitik.

Pada kedalaman $10,50 \mathrm{~m}$ s.d. $23,30 \mathrm{~m}$ terdiri dari batupasir kuarsa arenit dan berselingan dengan batulanau dengan struktur perlapisan masih nampak terlihat. Batupasir kuarsa arenit, berwarna coklat kekuningan, berukuran butir sedang dengan bentuk butir membulat dengan kemas tertutup dan pemilahan sedang. Batuan agak lapuk dan mineral kuarsa dominan selebihnya felspar. Gejala terkekarkan nampak terlihat dan hireline dari mineral besi serta retakan yang diisi oleh oksida besi dengan kerapatan 3\% s.d. $5 \%$.

Pada kedalaman $23,30 \mathrm{~m}$ s.d. $39,30 \mathrm{~m}$ terdiri dari batulanau berwarna kelabu dan berbutir halus. Batuan kondisinya kompak memperlihatkan perlapisan dengan sisipan batupasir kuarsa tebal $40 \mathrm{~cm}$, berwarna coklat-kekuningan dan mempunyai ukuran butir halus-sedang serta terkekarkan. Pada batupasir terlihat hair line dari mineral besi dengan kerapatan $1 \%$ dan urat halus kuarsa tebal $3 \mathrm{~mm}$, barren dengan orientasi $45^{\circ}$ terhadap sumbu inti pengeboran.

Pada kedalaman $39,30 \mathrm{~m}$ s.d. $80,80 \mathrm{~m}$ terdiri dari batupasir kuarsa arenit berwarna kuning sampai kecoklatan dan mempunyai ukuran butir sedang dengan bentuk butir membulat. Batuan memperlihatkan kemas tertutup dan pemilahan sedang. Gejala struktur nampak banyak batuan terkekarkan. Selain itu terdapat sisipan batulanau berwarna kelabu dan kompak. Di beberapa bagian seperti pada kedalaman $51,30 \mathrm{~m}$ teramati hair line mineral besi/timah agak intensif dengan kerapatan sekitar $5 \%$ yang dipotong oleh urat halus kuarsa dengan tebal $1 \mathrm{~mm}$ s.d. $3 \mathrm{~mm}$, barren dan orientasi $70^{\circ}$ s.d. $80^{\circ}$ terhadap sumbu inti bor (Gambar 7).

Dari hasil pemeriksaan sayatan tipis batuan menunjukkan tekstur klastik, closeopen packing, sortasi baik-sedang, berbutir sangat halus hingga berukuran $0,5 \mathrm{~mm}$, bentuk butir menyudut tanggungmembundar tanggung, diisi oleh fragmen kuarsa $(82 \%)$ dan felspar (trace) dengan semen ilit $(3 \%)$ di dalam matriks mineral lempung (15\%) (Gambar 8).

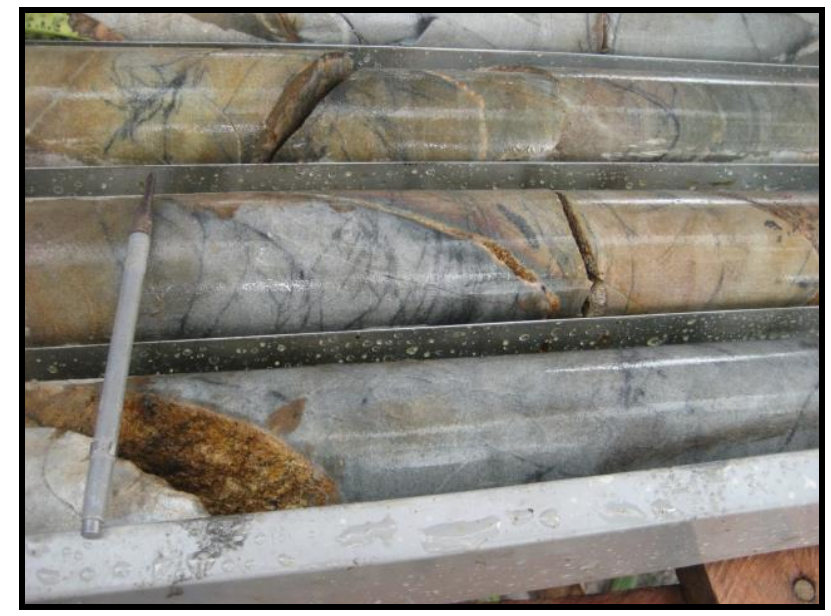

Gambar 7. Batupasir kuarsa arenit dengan hair line mineral besi/timah yang dipotong oleh urat kuarsa pada lubang pengeboran LB.01 kedalaman $51,30 \mathrm{~m}$ 
Pada kedalaman $76,80 \mathrm{~m}$ terdapat urat halus kuarsa dengan mineral pirit yang mengisi dalam retakan dan sedikit kloritisasi. Urat halus ketebalan $1 \mathrm{~mm}$ s.d. $3 \mathrm{~mm}$, dengan orientasi $50^{\circ}$ terhadap sumbu inti bor dan kerapatan 5\%. Hasil analisis mineragrafi conto BT/LB.01/014/2015 teridentifikasi mineral pirit $(3 \%)$, kalkopirit (trace), sfalerit $(<0,5 \%)$ dan kasiterit $(<0,5 \%)$. Tampak sfalerit menggantikan pirit (Gambar 9). Sedangkan dari hasil analisis kimia menunjukkan kandungan 5 ppm Sn.

Pada kedalaman $80,80 \mathrm{~m}$ s.d. $137,50 \mathrm{~m}$ terdiri dari batupasir kuarsa, kelabukehijauan, butir sedang, setempat memperlihatkan sedikit tekstur granoblastik, dipotong oleh urat halus kuarsa, kompak. Pada kedalaman $111,50 \mathrm{~m}$ s.d. $111,80 \mathrm{~m}$ urat halus kuarsa tebal $0,3 \mathrm{~cm}$, tekstur vugh-comb, mineralisasi pirit dan epidot, dengan orientasi $80^{\circ}$ s.d. $90^{\circ}$ terhadap sumbu inti bor. Sebagian berselingan dengan batulanau, kelabu kehijaun setempat terkekarkan dan milonitisasi.

Pada Kedalaman 137,50 m s.d. 175,0 m terdiri dari perselingan batupasir kuarsa dan batulanau, hijau kelabu, butir halus, berlapis baik. Setempat sisipan batupasir kuarsa, putih kelabu, butir halus-sedang, bentuk butir membulat, kemas tertutup, kompak. Pada bagian dasar terdapat batulanau, kehijauan, butir halus, terkekarkan, britle. Urat kuarsa tebal $1 \mathrm{~mm}$ s.d. $2 \mathrm{~mm}$, vugh, klorit pada tepi urat, mengandung pirit dalam retakan (1\%) dengan ubahan kloritisasi yang agak intensif. Pada kedalaman $161.70 \mathrm{~m}$ urat mengandung pirit, sphalerit, tebal $0,4 \mathrm{~cm}$, klorititisasi, $10^{\circ}$ s.d. $15^{\circ}$ terhadap sumbu inti bor.

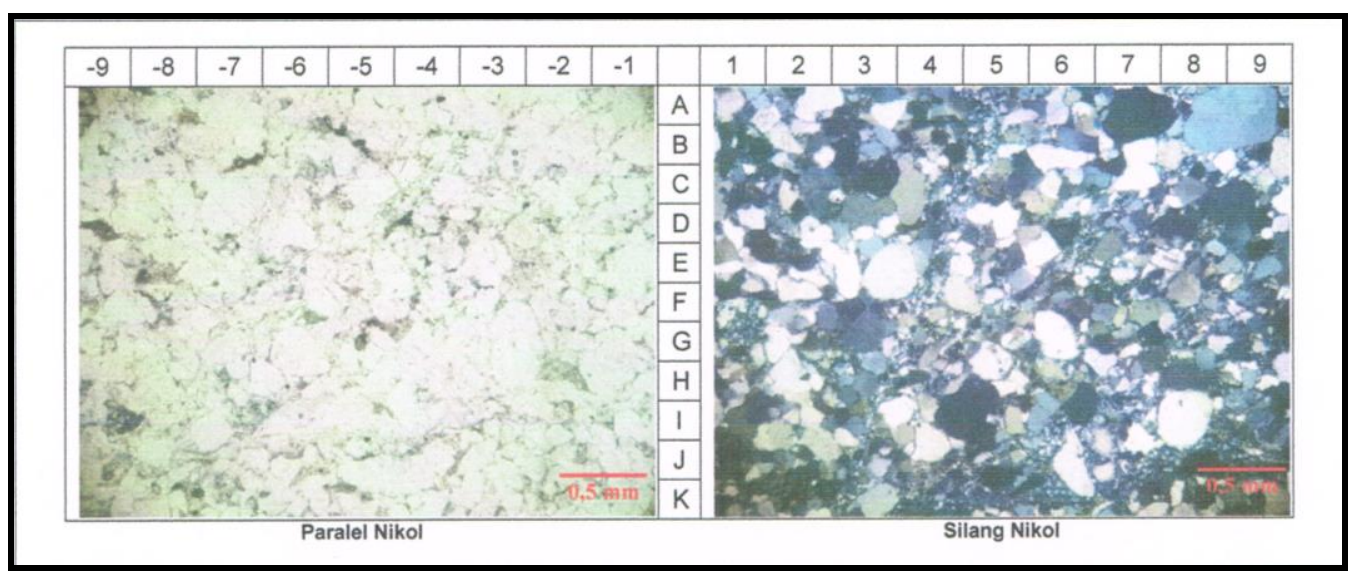

Gambar 8. Foto mikrograf batupasir kuarsa arenit tersusun oleh kuarsa $(A, 9 ;$ I 8), felspar semen ilit dan matriks mineral lempung (BT/LB.01/029/2015).

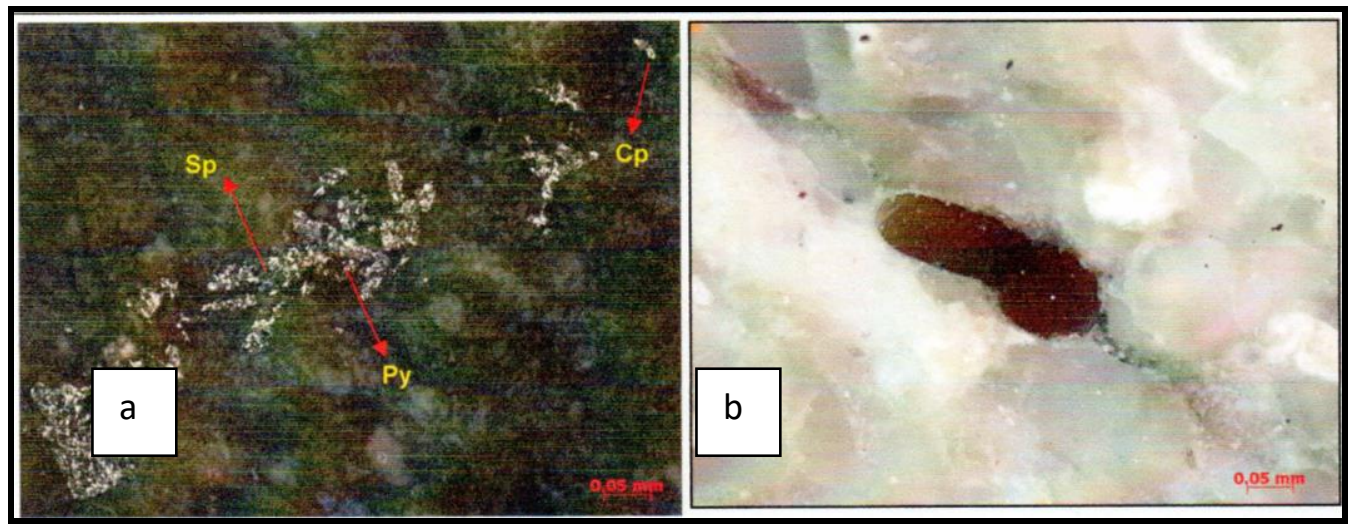

Gambar 9. a) Fotomikrograf sayatan poles pirit (Py), sfalerit (Sp) dan kalkopirit (Cp) dalam masa batuan. b) Fotomikrograf sayatan poles kasiterit dalam masa batuan 


\section{Titik Pengeboran LB.02}

Pada kedalaman $00,00 \mathrm{~m}$ s.d. $17,40 \mathrm{~m}$ merupakan endapan aluvial yang terdiri dari pasir, pasir lempungan, lempung, kuning kecoklatan-merah, lempungan dan beberapa mengandung material batupasir teroksidasi.

Pada kedalaman $17,40 \mathrm{~m}$ s.d. $54,95 \mathrm{~m}$ terdiri dari batupasir kuarsa, coklatkemerahan, berbutir sedang, dominan kuarsa sedikit lempung, kemas tertutup, pemilahan sedang, bentuk butir membulat, sisipan batu lempung-lanau, kelabu kecoklatan agak lapuk, butir halus, kompak. Pada kedalaman 28,35 s.d. $30,00 \mathrm{~m}$ teramati urat tipis kuarsa tebal $0,5 \mathrm{~cm}$ s.d. $1,0 \mathrm{~cm}$, putih susu, masifstruktur vugh, barren, kloritisasi di sekitar urat, orientasi $50^{\circ}$ terhadap sumbu inti dan teramati juga hair line mineral besi/timah dengan kerapatan $3 \%$.

Pada kedalaman $54,95 \mathrm{~m}$ s.d. $84,0 \mathrm{~m}$ terdiri dari perselingan batupasir kuarsalanau, kelabu, berbutir halus, pemilahan sedang, kemas tertutup, agak lapuk, tampak struktur lapisan, sedikit terkekarkan. Pada kedalaman 70,00 m s.d. $70,10 \mathrm{~m}$ urat kuarsa dan klorit tebal $0,1 \mathrm{~cm}$ s.d. $0,5 \mathrm{~cm}$ mengsisi retakan dan mengandung mineral besi/timah dengan kerapatan $5 \%$ serta orientasi $70^{\circ}$ terhadap sumbu inti bor. Dari hasil analisis mineragrafi conto BT/LB.02/013/2015 teridentifikasi mineral kasiterit $(0,5 \%)$, pirit
$(<0,5 \%)$, hematit $(1 \%)$, realgar $(2 \%)$, dan hydrous iron oxide (Gambar 10a). Sedangkan mineral realgar terlihat berupa urat halus dalam masa batuan (Gambar 10b). Hasil analisis kimia menunjukkan kandungan 15 ppm Sn.

Pada kedalaman $80,00 \mathrm{~m}$ terdapat retakan $1 \mathrm{~mm}$ s.d. $5 \mathrm{~mm}$, agak intensif yang terisi oksida besi, kuarsa dan bercak pirit dengan orientasi $45^{\circ}$ terhadap sumbu inti bor. Selain itu teramati pula hair line dari mineral molibdenit (Gambar 11). Dari hasil analisis mineragrafi conto BT.02/022/2015 teridentifikasi mineral gutit $(0,5 \%)$, pirit $(<0,5 \%)$, molibdenit $(1,5 \%)$, dan hydrous iron oxide (2\%) (Gambar 12a). Teramati pula molibdenit berupa urat dalam masa batuan (Gambar 12b). Sedangkan dari hasil analisis kimia kandungan mencapai 2 ppm Mo dan 147 ppm Zn.

Pada kedalaman $84,0 \mathrm{~m}$ s.d. $141,50 \mathrm{~m}$ terdiri dari batupasir kuarsa kelabukehijauan yang berselingan dengan batulanau berwarna kelabu kehijaun setempat tersesarkan dengan munculnya milonitisasi. Di beberapa tempat seperti pada kedalaman $104,30 \mathrm{~m}$, batuan ini dipotong oleh urat kuarsa putih susu, tebal $0,4 \mathrm{~cm}$, bersifat kompak dan barren dengan orientasi $20^{\circ}$ s.d. $40^{\circ}$ terhadap sumbu inti bor. Urat kuarsa ini memotong hair line mineral besi. Kemudian keduanya dipotong oleh urat kuarsa tebal $1 \mathrm{~mm}$, sedikit pirit, masif sampai vugh dengan orientasi $80^{\circ}$ terhadap sumbu inti bor.

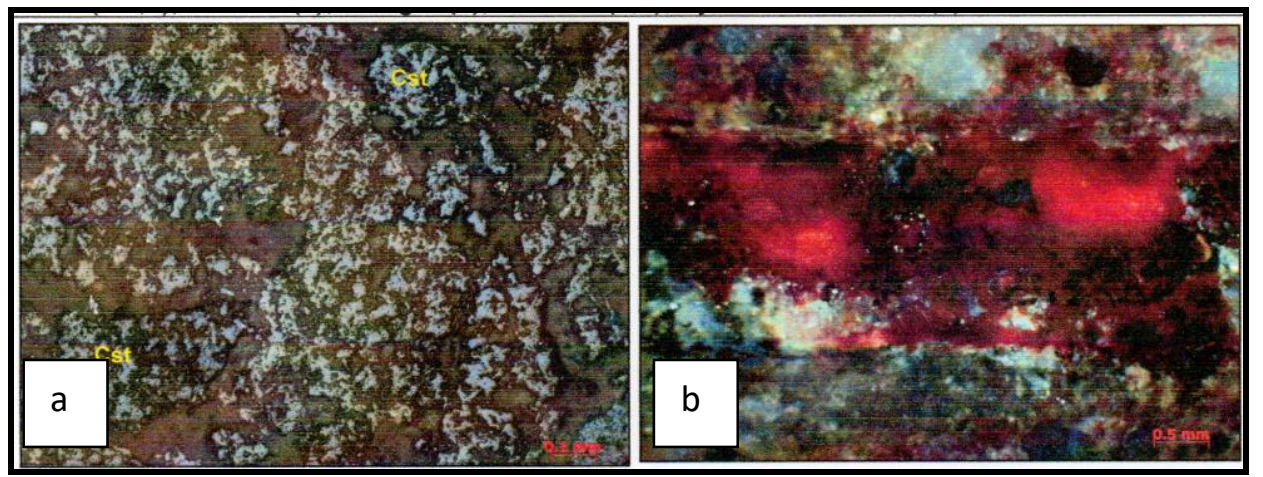

Gambar 10. a) Fotomikrograf sayatan poles kasiterit (Cst) dalam masa batuan.

b) Fotomikrograf sayatan poles realgar dalam massa batuan terlihat refleksi dalam berwarna orange kemerahan. 


\section{MAKALAH ILMIAH}

Pada kedalaman 131,35 m teramati adanya urat tipis kuarsa 1 s.d. $2 \mathrm{~mm}$, bercak pirit, vugh dengan orientasi $45^{\circ}$ terhadap sumbu inti bor yang memotong hair line mineral besi / timah. Juga bercak pirit teramati dalam masa batuan (Gambar 13). Hasil analisis dari conto nomor BT/LB.02/048/2015 menunjukkan kandungan 18 ppm Sn, 126 ppm Pb, 184 ppm Zn dan $3,01 \% \mathrm{Fe}$.
Pada kedalaman 141,50 s.d. $175,00 \mathrm{~m}$ terdiri dari terdiri atas metabatupasir kuarsa/kuarsit berwarna hijau-kelabu, keras dan kompak, memperlihatkan tekstur granoblastik dan rekristalisasi kuarsa yang dipotong urat kuarsa. Batuan ini dipotong urat kuarsa dengan tebal $1 \mathrm{~mm}$ s.d. $2 \mathrm{~mm}$, tekstur vugh dan mengandung klorit pada tepi urat, serta pirit dalam retakan (1\%) dengan ubahan kloritisasi yang agak intensif.

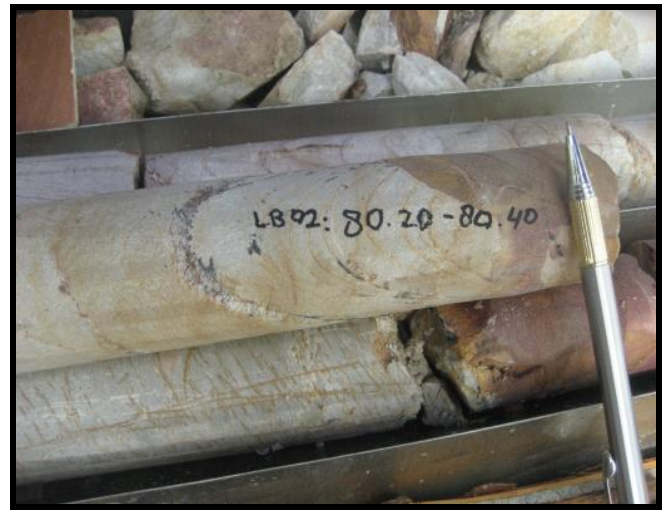

Gambar 11. Urat kuarsa yang mengandung oksida besi dan molibdenit pada batupasir kuarsa lubang pengeboran LB.02 kedalaman 80,20 s.d. 80,40 m

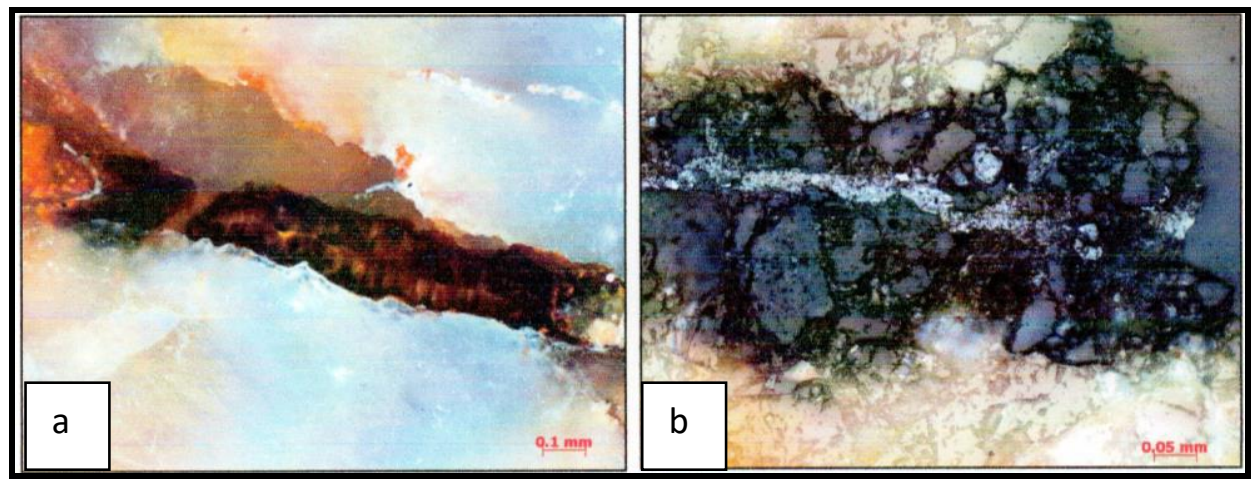

Gambar 12. a) Fotomikrograf sayatan poles gutit dalam masa batuan.

b) Fotomikrograf sayatan poles molibdenit dalam masa batuan

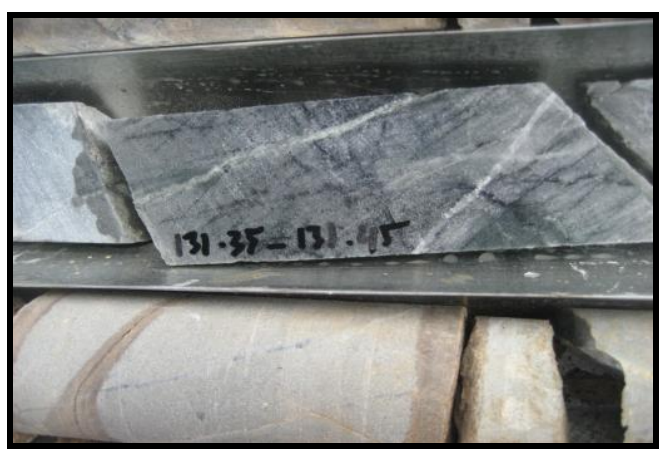

Gambar 13. Urat kuarsa dengan bercak pirit memotong hair line mineral besi/timah conto BT/LB.02/046/2015 
Pada kedalaman $160 \mathrm{~m}$ s.d. $161 \mathrm{~m}$ teramati kloritisasi dalam urat tipis berasosiasi dengan kuarsa, hair line mineral besi agak intensif dengan kerapatan 4\%. Selain itu bercak pirit teramati dalam masa batuan dan urat tipis. Pada kedalaman 161,70 m urat kuarsa mengandung pirit, sfalerit dan klorit serta tebal $0,4 \mathrm{~cm}$ dengan orientasi $10^{\circ}$ s.d. $15^{\circ}$ terhadap sumbu inti bor.

Pada kedalaman $170.10 \mathrm{~m}$ teramati ubahan silisifikasi dan terdapat urat kuarsa polimetalik (galena, sfalerit, pirit dan kasiterit), tebal $0,5 \mathrm{~cm}$ s.d. $0,7 \mathrm{~cm}$ dengan orientasi $80^{\circ}-70^{\circ}$ terhadap sumbu inti bor. Mineral sulfida yang teramati antara lain galena, sfalerit, pirit dan kasiterit (Gambar 14). Hasil analisis mineragrafi conto BT/LB.02/065/2015 teridentifikasi mineral pirit $(1 \%)$, kalkopirit $(1 \%)$, sfalerit $3 \%)$, galena $(7 \%)$ dan kalkosit $(0,5 \%)$ (Gambar 15a). Tampak kalkosit merupakan mineral hasil oksidasi dari kalkopirit (Gambar 15b). Sedangkan dari hasil analisis kimia menunjukkan kandungan 306 ppm Pb dan 147 ppm Zn.

Gambar 14. Urat kuarsa polimetalik mengandung galena, pirit dan sfalerit pada lubang pengeboran LB.02 kedalaman 170,10 m

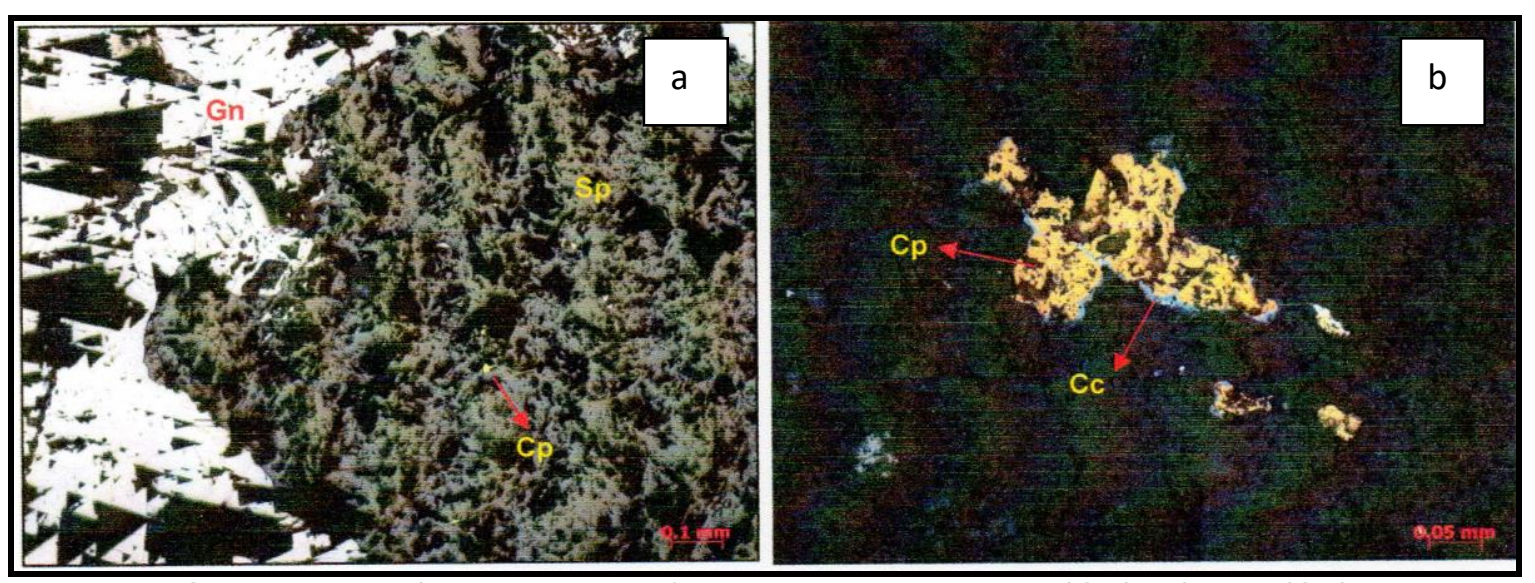

Gambar 15. a) Fotomikrograf sayatan poles galena (Gn), sfalerit (Sp)

dan kalkopirit (Cp) dalam masa batuan. b) Fotomikrograf sayatan poles kalkopirit (Cp) dan kalkosit (Cc) dalam masa batuan 


\section{Titik Pengeboran LB.03}

Pada kedalaman $0,00 \mathrm{~m}$ s.d. $03,10 \mathrm{~m}$ terdiri dari gossan, coklat kemerahan sebagian lempungan, fragmen dari hematit, gutit dan urat-urat limonit. Pada kedalaman 03,10 s.d. $24,90 \mathrm{~m}$ terdiri dari Lempung dan lempung pasiran, setengah lapuk, merah kecoklatan, sedikit ada fragmen batu lempung coklat. Pada kedalaman 24,90 s.d. $87,90 \mathrm{~m}$ terdiri dari batupasir kuarsa, butir sedang, bentuk membulat, kelabu kecoklatan, terkekarkan kuat, dominan kuarsa dan sedikit felspar, fragmen kuarsa dalam matrik silika. Pada beberapa bagian berselingan dengan batu lempung tufaan dan batulanau butir halus kelabu sebagian kecoklatan, terkekarkan dan terisi oleh oksida besi beberapa berupa menjaring. Pada kedalaman $27,00 \mathrm{~m}$ s.d. $27,90 \mathrm{~m}$ terdapat urat kwarsa mengandung pirit, tebal $1 \mathrm{~mm}$ s.d. $3 \mathrm{~mm}$, kloritisasi dan dan sebagian hair line besi/timah. Pada kedalaman $61,10 \mathrm{~m}$ s.d. $66,0 \mathrm{~m}$ terdapat urat kuarsa masif, putih susu, tebal $2 \mathrm{~cm}$, mengandung bercak pirit, pada tepi urat ada klorit dan hair line besi/galena dengan kerapatan $1 \%$ dan zona breksiasi urat kuarsa, masif, limonitik (Gambar 16). Hasil analisis kimia pada conto nomor BT/LB.03/021/2015 menunjukkan kandungan $60 \mathrm{ppm}$ Sn dan 353 ppm $\mathrm{Pb}$.

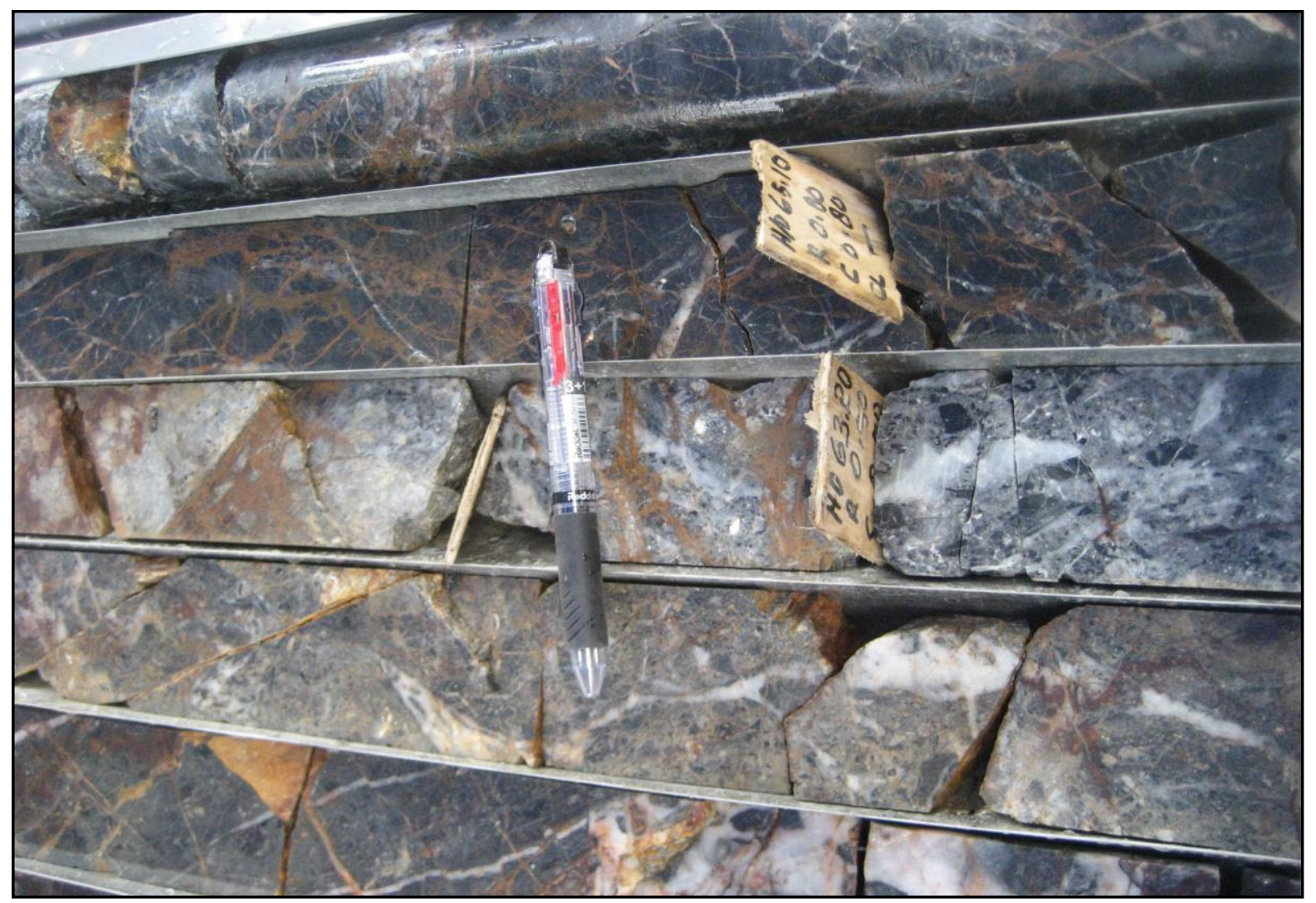

Gambar 16. Zona breksiasi dengan matrik yang terisi oleh silika dan urat kuarsa terbreksikan pada kedalaman $61,00 \mathrm{~m}$ s.d. $66,00 \mathrm{~m}$ di LB.03 
Pada kedalaman $87,90 \mathrm{~m}$ s.d. $164,80 \mathrm{~m}$ terdiri dari batupasir kuarsa kelabu, butir sedang, bentuk membulat, kemas terbuka, pemilahan sedang, dipotong oleh urat kwarsa. Pada 107,50 m terdapat gejala sheared akibat patahan. Pada kedalaman $111,0 \mathrm{~m}$ s.d. $115,0 \mathrm{~m}$, limonitik kuat dan sebagaian membentuk jarosit dengan urat halus besi/timah kerapatan $1 \%$. Selain itu urat tipis kuarsa tebal $1 \mathrm{~mm}$ s.d. $2 \mathrm{~mm}$, kristalin, sedikit mengandung mineral besi/timah, orientasi $60^{\circ}$ terhadap sumbu inti bor. Di beberapa bagian terdapat sisipan batulanau, kelabu-kecoklatan, terbreksikan, dengan fragmen menyudut dalam matrik lempung, diduga pada zona patahan. Pada kedalaman $141,40 \mathrm{~m}$ s.d. $143,40 \mathrm{~m}$ batupasir kuarsa dengan ubahan limonitik kuat, banyak mengandung hair line mineral besi/timah dan sedikit pola menjaring yang terisi limonit dengan kerapatan 30\%. Mulai kedalaman 147,90 m terdapat ubahan kloritisasi kuat, serisit pada masa batuan dengan hair line mineral besi/timah dengan kerapatan $30 \%$.

Pada kedalaman 164,80 m s.d. $175,0 \mathrm{~m}$ terdiri dari meta batupasir kuarsa/kuarsit dengan sisipan batulanau, kehijauan, granoblastik. Pada masa batuan teramati bercak pirit dengan urat tipis kuarsa dan serisit, tebal $1 \mathrm{~mm}$, ubahan kloritisasi kuat dan terdapat hair line mineral besi/timah. kedalaman $170,80 \mathrm{~m}$. Dari pemeriksaan sayatan tipis pada conto BT/LB.03/053/2015 menunjukkan tektur kristalin, sugary, mosaic interlocking, fractured, berbutir halus hingga berukuran $0,3 \mathrm{~mm}$, bentuk butir subhedral-anhedral, disusun oleh fenokris kuarsa $(80 \%)$, muskovit (4\%) dan mineral opak $(2 \%)$, berasosiasi dengan klorit (8\%) dan serisit $(6 \%)$. Juga terlihat terobosan urat kuarsa (Gambar 17).

Berdasarkan rekonstruksi dari hasil ketiga titik pengeboran terlihat kecenderungan batuan kuarsit-granit aplitik umumnya hanya berkembang pada bagian bawah dari inti bor. Pola pengembangan batuan ini juga diikuti oleh pola penyebaran ubahan kloritisasi pada batuan. Sedangkan indikasi pola kelurusan urat kuarsa polimetalik yang mengandung mineralisasi galena, sfalerit dan besi sebagaimana dijumpai pada lubang pengeboran LB.02 nampaknya mengarah ke barat sehingga memotong pada lubang pengeboran LB.01. Kemungkinan urat ini juga diperkirakan memotong lubang pengeboran LB.03 namun pada tempat yang lebih dalam. Piritisasi dalam bentuk bercak pirit dan beberapa berupa pengisian retakan terdapat hampir di semua lubang pengeboran. Namun intensitas piritisasi menunjukkan gejala yang berbeda.

Setempat batuan ini diterobos oleh granit aplitik sebagaimana yang dijumpai pada

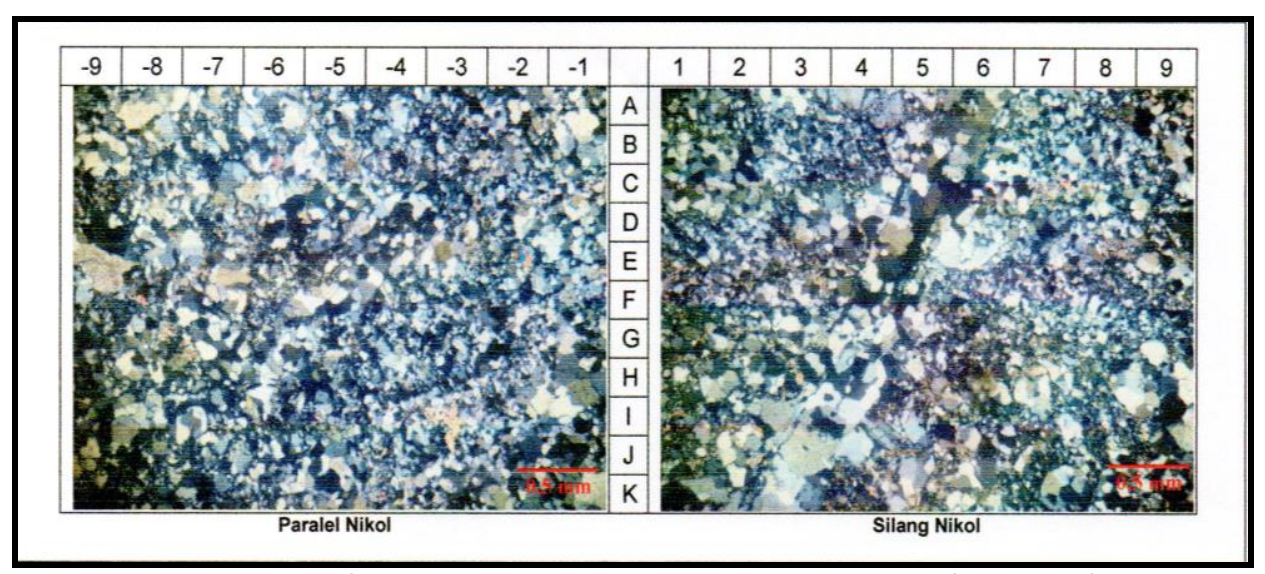

Gambar 17. Fotomikrograf granit aplitik tersusun oleh kuarsa $(H, 9 ; J, 3)$, muskovit $(E,-2)$, serisit, klorit dan mineral opak. 


\section{MAKALAH ILMIAH}

Sebagian pirit kubik yang diduga berhubungan dengan zona patahan terdapat pada lubang pengeboran LB.03. Sedangkan sebagian lainnya adalah pirit yang kemungkinan terbentuk akibat dari proses malihan yang berasosiasi dengan sebaran batuan kwarsit akibat terobosan batuan aplit granit. Hasil analisis XRF batuan aplit granit (BT/LB.03/053/2015) memperlihatkan kandungan $88,90 \% \mathrm{SiO}_{2}$; $6,25 \% \quad \mathrm{Al}_{2} \mathrm{O}_{3} ; \quad 0,01 \% \quad \mathrm{Na}_{2} \mathrm{O} ; \quad 0,43 \% \quad \mathrm{~K} \mathrm{~K}_{2} \mathrm{O}$; $0,013 \mathrm{CaO} ; 0,76 \% \mathrm{FeO}$ dan $2,24 \% \mathrm{MgO}$ (Tabel 1).
Hasil analisis kimia pengeboran inti menunjukkan sebaran rinci kandungan tembaga pada tiap penampang lubang pengeboran paling tinggi terdapat pada LB.03 hingga mencapai 441 ppm Cu (Gambar 18). Sedangkan untuk kandungan timbal terdapat pada LB.02 yang mencapai $2280 \mathrm{ppm} \mathrm{Pb}$ (Gambar 19) dan kandungan seng pada LB.02 mencapai 2430 ppm Zn (Gambar 20). Untuk sebaran kandungan timah menunjukkan bahwa konsentrasi timah lebih banyak berada pada lubang pengeboran LB.03 hingga mencapai 60 ppm Sn (Gambar 21).

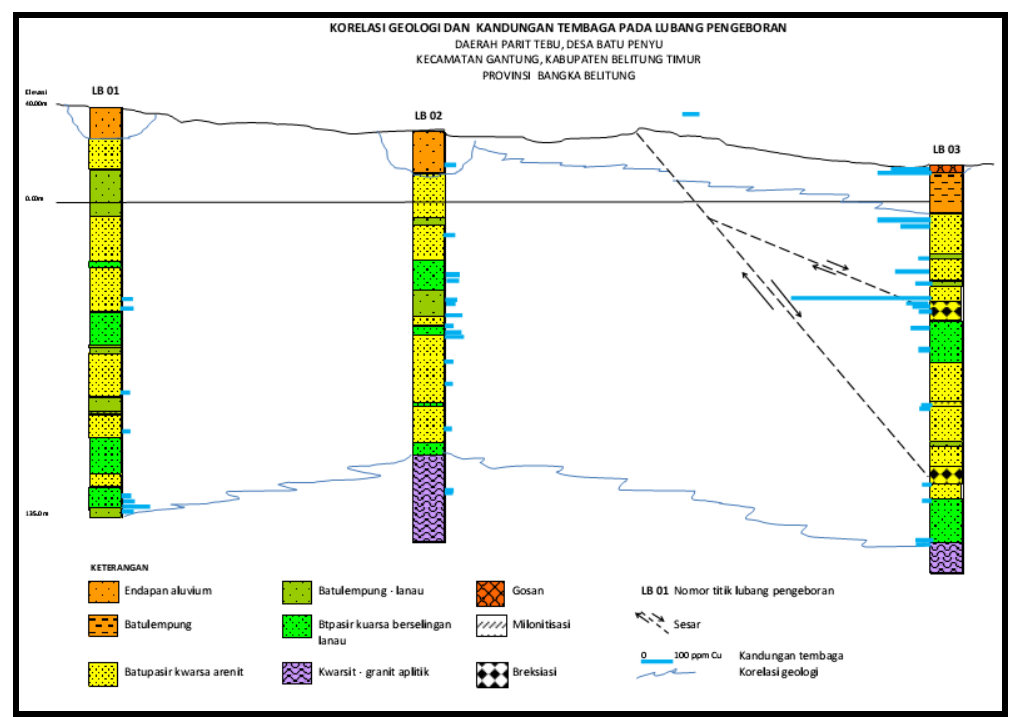

Gambar 18. Korelasi geologi dan kandungan unsur Cu pada lubang pengeboran (Soepriadi, dkk., 2015)

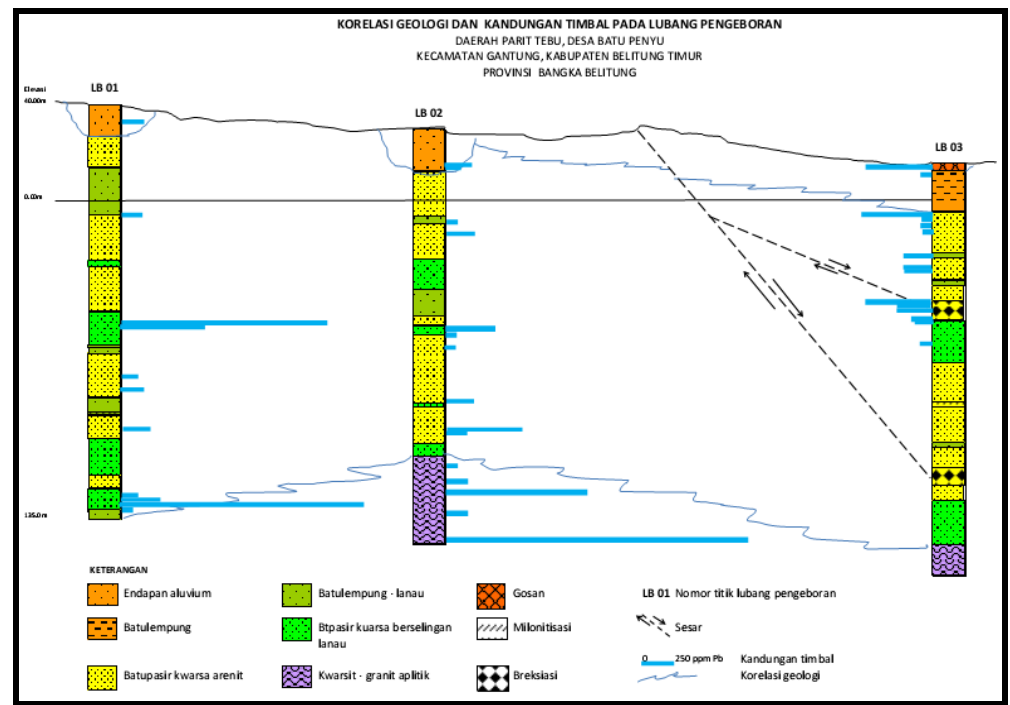

Gambar 19. Korelasi geologi dan kandungan unsur $\mathrm{Pb}$ pada lubang pengeboran (Soepriadi, dkk., 2015) 


\section{MAKALAH ILMIAH}

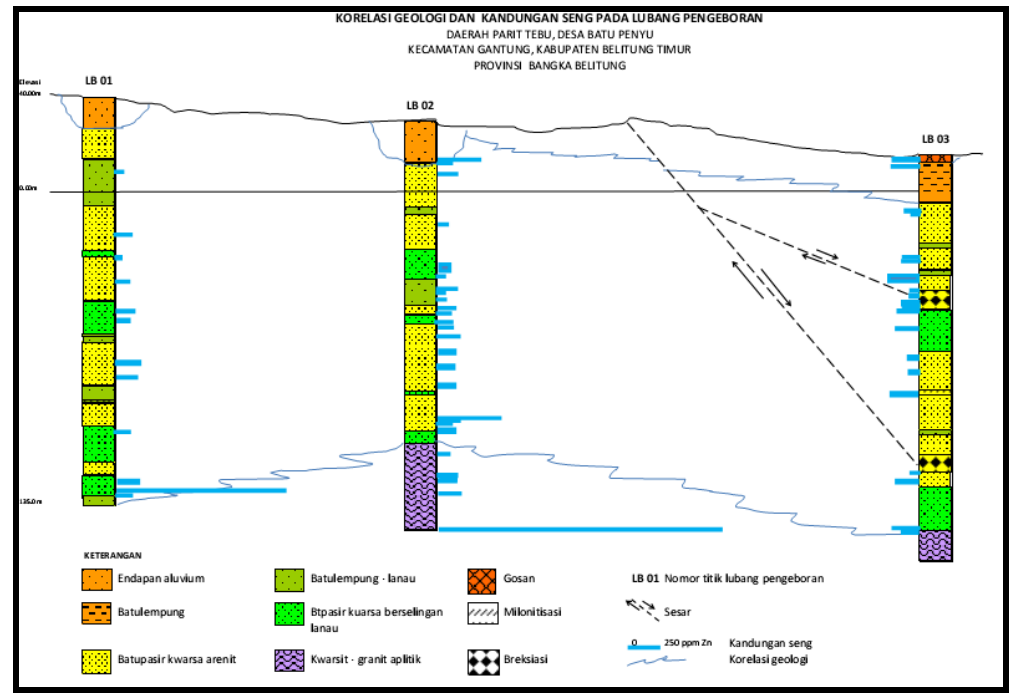

Gambar 20. Korelasi geologi dan kandungan unsur Zn pada lubang pengeboran

(Soepriadi, dkk., 2015)

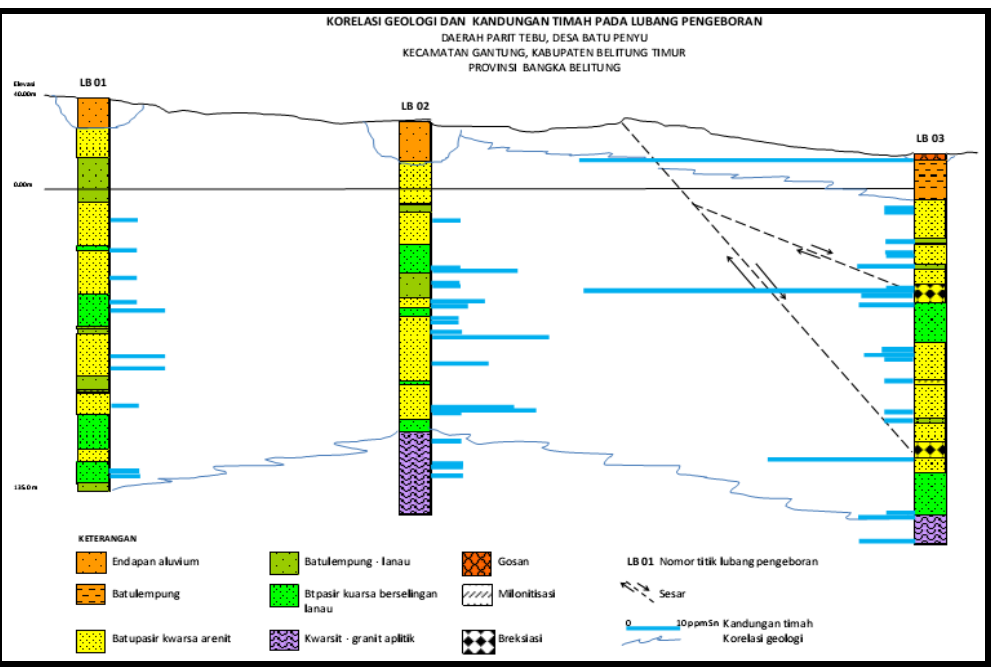

Gambar 21. Korelasi geologi dan kandungan unsur Sn pada lubang pengeboran (Soepriadi, dkk., 2015)

Tabel 1. Hasil analisis XRF conto batuan inti pengeboran

\begin{tabular}{|c|c|c|c|c|c|c|c|c|c|c|c|c|c|c|}
\hline \multirow{3}{*}{ NO. } & \multicolumn{2}{|l|}{ METODA } & \multicolumn{8}{|c|}{ KF-III.32.20 IKNL } & \multicolumn{4}{|c|}{$\begin{array}{c}\text { ASTM C- } \\
25-2006\end{array}$} \\
\hline & KODE & $\mathrm{SiO}_{2}$ & $\mathrm{Al}_{2} \mathrm{O}_{3}$ & $\mathrm{Fe}_{2} \mathrm{O}_{3}$ & $\mathrm{CaO}$ & MgO & $\mathrm{Na}_{2} \mathrm{O}$ & $\mathrm{K}_{2} \mathrm{O}$ & $\mathrm{TiO}_{2}$ & MnO & $\mathrm{P}_{2} \mathrm{O}_{5}$ & $\mathrm{SO}_{3}$ & $\mathrm{H}_{2} \mathrm{O}^{-}$ & HD \\
\hline & & $\%$ & $\%$ & $\%$ & $\%$ & $\%$ & $\%$ & $\%$ & $\%$ & $\%$ & $\%$ & $\%$ & $\%$ & $\%$ \\
\hline 1 & BT/LB. & & 6.8 & & & & & 0.70 & & & & 0.00 & & \\
\hline 2 & & 3.43 & 7.2 & & & & & 0.63 & 0. & 0. & 0 & & & \\
\hline 3 & & & $\mathrm{~N}$ & & & & & NS & & 7 & $\mathrm{~N}$ & NS & & NS \\
\hline 4 & BT/L & .42 & 16.13 & 1.91 & 8 & 2.90 & & 4.46 & 4 & 0.71 & 20 & .02 & .02 & 0.42 \\
\hline 5 & BT/LI & 5.52 & 9.65 & 47 & 0.17 & 2 & & 1.98 & 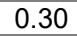 & 0.04 & + & .00 & & .06 \\
\hline 6 & BT/LB.02/071/2015 & 85.26 & 10.36 & 0.72 & 0.16 & 1.52 & 0.01 & 1.44 & 0.34 & 0.19 & 0.09 & 0.00 & 1.51 & .08 \\
\hline 7 & BT/LB.03/035/2015 & 92.33 & 5.31 & 0.82 & 0.09 & 1.37 & 0.01 & 0.34 & 0.21 & 0.04 & 0.04 & 0.00 & 0.99 & 0.18 \\
\hline 8 & BT/LB.03/053/2015 & 88.90 & 6.25 & 0.76 & 0.13 & 2.24 & 0.01 & 0.43 & 0.25 & 0.10 & 0.08 & 0.00 & 1.11 & 0.11 \\
\hline
\end{tabular}

\section{PEMBAHASAN}

Proses mineralisasi cebakan timah primer di daerah Pulau Belitung berhubungan dengan larutan hidrotermal yang dihasilkan oleh intrusi batuan berkomposisi asam (granit tipe S). Di daerah Tikus mineralisasi timah primer mempunyai tipe greisen ditemukan dalam batuan granit Tanjung Pandan yang 
merupakan granit tipe-S berumur Trias. Selain itu di daerah Batubesi terdapat mineralisasi timah yang berasosiasi dengan logam dasar dalam cebakan tipe skarn akibat kontak antara batuan diorit kuarsa Batubesi berumur Kapur dengan batuan metasedimen (Anonim, 2001).

Berdasarkan evaluasi dari lubang pengeboran LB.01, LB.02 dan LB.03 di daerah penelitian, mineralisasi timah primer secara kasat mata tidak nampak jelas. Hal ini sangat berbeda dengan mineralisasi yang teramati di permukaan dimana dalam singkapan batupasir kuarsa arenit mineralisasi berasosiasi dengan urat kuarsa tipis, transparan-kristalin yang mengandung kasiterit, monasit, hematit dan gutit. Namun demikian ada beberapa pengamatan dalam batuan inti pengeboran mineralisasi timah hadir bersama dengan besi dalam bentuk urat halus / hair line yang banyak memotong dalam batupasir arenit maupun perselingan batupasir-lanau. $\mathrm{Hal}$ ini nampak jelas terlihat pada fenomena urat halus / hair line tersebut, sebagian urat halus terubah menjadi limonit/oksida besi yang berwarna coklat, sedangkan yang lainnya tetap berwarna hitam yang diduga mengandung kasiterit dan galena berukuran halus. Setempat juga teramati ada bercak mineral pirit. Hasil pemeriksaan mineragrafi terlihat kasiterit hadir tersebar tidak merata dalam masa batuan dan berupa urat-urat halus yang berasosiasi dengan realgar, pirit, sfalerit, galena dan kalkopirit. Selain itu juga teramati adanya urat halus yang terisi oleh mineral realgar dan molibdenit.

Mineralisasi cebakan timah primer di sekitar daerah penelitian diawali dengan pembentukan hair line dan sebagian urat kuarsa mengandung timah yang merupakan tahap pertama proses mineralisasi di daerah ini. Kemudian proses mineralisasi tahap kedua yang diperkirakan berhubungan dengan intrusi adamelit Baginda yang berumur Jura. Sisa larutan hidrothermal ini yang menyebabkan terbentuknya urat kuarsa berwarna putih susu dan sedikit mengandung bercak pirit. Urat-urat kuarsa ini dalam batuan terlihat memotong hair line mineral besi yang terbentuk pada tahap pertama. Akibat terobosan ini larutan yang melalui zona patahan kemungkinan dapat membentuk mineralisasi besi yang dominan baik dalam bentuk pengisian rekahan maupun bijih. Hal ini terlihat ditemukannya zona patahan yang matriknya terisi oleh kuarsa putih susu dan masif. Mineralisasi yang teramati hanya bercak pirit dan oksida besi. Selain itu juga ditemukannya gossan dengan mineral hematit, gutit dan oksida besi.

Proses mineralisasi yang terakhir diperkirakan akibat terobosan batuan diorit kuarsa Batubesi yang juga berumur Kapur. Mineralisasi yang terbentuk lebih banyak ditemukan dalam kuarsit. Sebagian ditemukan juga dalam batupasir kuarsa arenit berselingan dengan batulanau. Tipe mineralisasi berupa urat halus/urat kuarsa yang mengandung mineral galena, sfalerit, pirit, kalkopirit, kasiterit, realgar dan molibdenit. Hadirnya mineral realgar dan molibdenit pada mineralisasi polimetalik menunjukkan bahwa pembentukannya berhubungan dengan urat hidrothermal (Whitten, dkk., 1972). Selain itu mineral klorit juga teramati pada sekitar urat halus dan pada masa batuan. Urat kuarsa ini dalam batuan memotong hair line besi dan urat kuarsa masif yang terbentuk pada tahap pertama dan kedua.

Dari hasil pengeboran hanya satu lubang yang terindikasi menembus batuan beku yaitu berupa granit aplitik pada LB.03 yang diperkirakan sebagai bagian dari intrusi diorit kuarsa Batubesi sehingga diduga telah mengakibatkan terbentuknnya meta batupasir/kwarsit yang diikuti dengan mineralisasi polimetalik tipe urat mengandung kasiterit, galena, sfalerit, pirit dan kalkopirit.

Hasil analisis XRF batuan aplit granit (BT/LB.03/053/2015) memperlihatkan kandungan 88,90\% $\quad \mathrm{SiO}_{2} ; 6,25 \% \quad \mathrm{Al}_{2} \mathrm{O}_{3}$; $0,01 \% \quad \mathrm{Na}_{2} \mathrm{O} ; \quad 0,43 \% \quad \mathrm{~K} 2 \mathrm{O} ; 0,013 \mathrm{CaO}$; 
$0,76 \% \mathrm{FeO}$ dan 2,24\% $\mathrm{MgO}$. Menurut Chappel dan White (1974) granit tipe-I memiliki natrium yang relatif tinggi, $\mathrm{Na}_{2} \mathrm{O}$ lebih besar dari 3,2\% dalam batuan felsik dan menurun menjadi kurang dari 2,2\% pada jenis batuan mafik. Sedangkan granit tipe-S memiliki natrium yang relatif rendah, $\mathrm{Na}_{2} \mathrm{O}$ biasanya kurang dari $3,2 \%$ dalam batuan dengan kandungan sekitar $5 \% \mathrm{~K}_{2} \mathrm{O}$ dan menurun menjadi kurang dari 2,2\% dalam batuan dengan kandungan sekitar $2 \% \mathrm{~K}_{2} \mathrm{O}$. Selanjutnya telah ditentukan untuk membedakan dua tipe batuan granit tersebut dengan perbandingan molar (molar ratio): $\mathrm{Al}_{2} \mathrm{O}_{3} /\left(\mathrm{Na}_{2} \mathrm{O}+\mathrm{K}_{2} \mathrm{O}+\mathrm{CaO}\right)$ untuk tipe-S hasilnya lebih besar dari 1,1 sedangkan untuk tipe-I kurang dari 1,1.

Berdasarkan penentuan tipe granit tersebut, hasil molar ratio pada conto di daerah penyelidikan mencapai 13,796 $(>1,1)$. Dengan demikian maka dapat disimpulkan bahwa granit daerah penyelidikan termasuk ke dalam granit seri-ilmenit atau granit tipe-S. Terkait dengan tipe batuan granit di daerah penyelidikan, kemungkinan keterdapatan sumber daya mineral selain logam tanah jarang adalah endapan timah (tipe greisen) pada umumnya terjadi di dalam batuan granit seri-ilmenit atau granit tipe-S (Ishihara, 1980).

Model cebakan greisen terdiri atas kasiterit tersebar dan urat urat halus yang mengandung kasiterit, stockwork, lensa, pipa dan breksi dalam mineral gangue berkomposisi kuarsa, mika, florit dan topas. Cebakan urat dan greisen ditemukan dalam dan dekat dengan terbentuknya batuan plutonik yang mengandung REE, khususnya dekat dengan kontak batuan samping pada area cupola batolit granit timah termobilisasi dalam lingkungan asam yang rendah (Rose, dkk., 1979). Kasiterit adalah mineral bijih timah utama, sangat tahan terhadap pelapukan kimia dan fisika dan cenderung terkonsentrasi dalam endapan eluvial dan aluvial.
Kandungan mineral sulfida pada bijih timah umumnya rendah. Dalam bijih ini mineral sulfida utama meliputi pirit, kalkopirit, galena dan arsenopirit. Mineralisasi timah terdapat pada batupasir kuarsa arenit dan meta batulempung. Pengayaan kandungan timah tinggi teridentifikasi berasosiasi kuat dengan tembaga terdapat pada LB.03 yang hanya terkonsentrasi pada zona urat yang terbreksikan. Sedangkan kandungan timbal dan seng relatif tinggi terdapat pada LB.01 dan LB.02 yang merupakan pencerminan dari keberadaan urat logam dasar yang memotong batuan induk. Batuan induk dan bijih mungkin kaya molibdenum, thorium dan uranium dimana unsur-unsur ini termobilisasi dalam lingkungan asam yang tinggi.

Dari skema model cebakan tersebut nampaknya di daerah penelitian yang berkembang adalah cebakan timah tipe urat polimetalik yang berada pada bagian atas sistem pembentukan cebakan (Gambar 22).

Hasil survey geofisika sebaran anomali tahanan jenis (resistivity) dan chargeability pada lintasan $E$ dimana lintasan ini melewati lokasi titik bor LB.02, menunjukkan nilai tahanan jenis rendah yang meningkat tinggi ke arah dalam. Nilai tahanan jenis rendah ini merupakan pencerminan batuan yang bersifat kurang resistif konduktif yaitu berupa batuan sedimen. Sedangkan nilai tahanan jenis yang tinggi merupakan pencerminan batuan yang lebih resistif dalam hal ini batuan metasedimen/kuarsit. Batuan yang mengandung mineral sulfida umumnya memiliki nilai tahanan jenis rendah (konduktif), sedangkan sifat kemagnitannya relatif lebih tinggi dari batuan di sekitarnya. Nilai chargeability rendah mengindikasikan sedikitnya kandungan mineral yang dapat menyimpan arus. Sedangkan chargebility tinggi relatif berhubungan keberadaan urat kuarsa yang mengandung galena, spalerit dan bercak pirit. 


\section{MAKALAH ILMIAH}

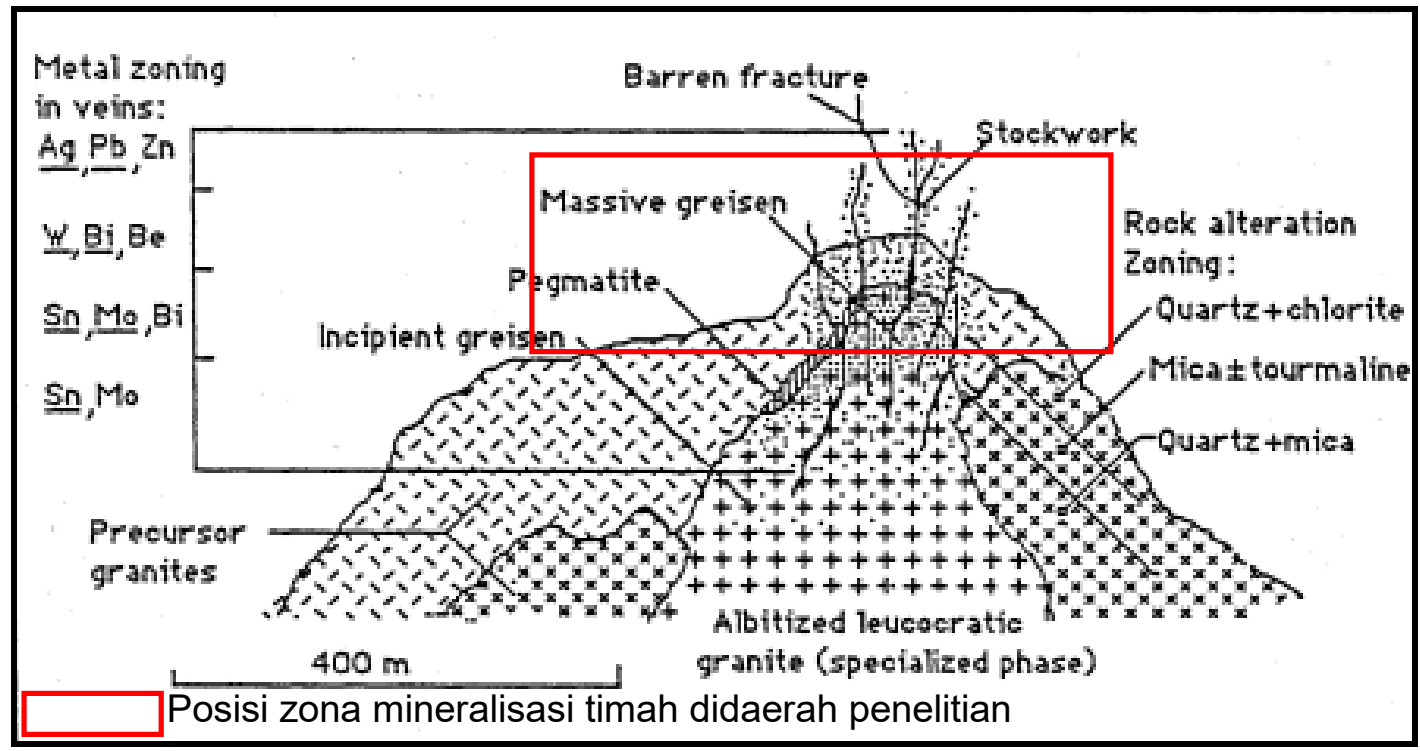

Gambar 22. Skema model cebakan timah primer (diadopsi dari Reed, 1986a)

Survei magnetik, gravity dan radiometrik dapat digunakan untuk menentukan area yang prospek adanya granit leucokratik (Hoover, dkk., 1992). Granit ini cenderung berasosiasi dengan gravity dan magnetik rendah mengandung jumlah unsur radioelemen (uranium, thorium dan potasium). Pada sekala cebakan dan kasus bijih dengan sulfida tinggi dapat digunakan audio-magnetotellurik, polarisasi terimbas (IP) dapat digunakan untuk memetakan variasi resistivity batuan karena kandungan mineral sulfida.

\section{KESIMPULAN}

Kondisi geologi bawah permukaan didominasi oleh batupasir kuarsa arenit, batulanau, perselingan batupasir kuarsalanau dan batu lempung yang sebagian diterobos oleh batu granit aplit terutama pada bagian bawah. Batuan tersebut selaras dengan respons geofisika yang menunjukkan resistivity dan chargebility yang umumnya bernilai rendah yaitu pada LB.01 dan LB.02. Pada LB.03 anomali magnit yang muncul nampaknya mempunyai korelasi dengan batu granit aplit yang menerobos batuan metasedimen.
Mineralisasi timah primer (kasiterit) terdapat pada batupasir kuarsa arenit dan metabatulempung yang mempunyai cebakan tipe urat polimetalik berasosiasi dengan realgar, molibdenit, galena, tembaga dan sfalerit dalam mineral gangue kuarsa. Kandungan timah dan tembaga relatif tinggi terkonsentrasi hanya pada zona urat kuarsa yang terbreksikan.

\section{UCAPAN TERIMA KASIH}

Penulis mengucapkan terima kasih kepada Kepala Pusat Sumber Daya Mineral Batubara dan Panas Bumi yang telah memfasilitasi kegiatan lapangan dan rekan-rekan tim eksplorasi yang membantu pengolahan data sehingga terwujudnya makalah ini.

\section{DAFTAR PUSTAKA}

Anonim, 2001, Exploration report on Belitung Project, Belitung Island, Join Venture between PT. Timah and Herald Resources Ltd.

Azis, Y.M., dan S. Widodo, 2014, Survei Polarisasi Terimbas (IP) dan Geomagnit Daerah Parit Tebu Kecamatan Gantung Kabupaten Belitung Timur, Provinsi Kepulauan Bangka Belitung, Pusat Sumber Daya Geologi, Bandung. 
Baharudin dan Sidarto, 1995, Peta Geologi Lembar Belitung, Sumatera, sekala 1: 250.000, Pusat Penelitian dan Pengembangan Geologi, Bandung.

Chappel, B.W., and White, A.J.R., 1974. Two contrasting granite types, Pacific Geol., 8, 173-174.

Hoover, D.B., Heran, W.D., and Hill, P.L., 1992, The geophyasical expression of selected mineral deposit models: U.S. Geological Survey Open-File Report 92-557, 129 p.

Ishihara, S., 1980, Granitic Magmatism and Related Mineralization, Mining Geology Special Issue No.8, 1980, The Society of Mining Geology of Japan, p. 13-28.

Lehmann, B., 1990, Metallogeny of Tin. Lecture notes in Earth Sciences., 32. Springer-Verlag, Berlin.

Reed, B.L., 1986 a, Descriptive model of Sn veins, in Cox, D.P., and Singer, D.A., eds, Mineral deposit models; U.S. Geological Survey Bulletin 1963, p.70.

Rose, A.W., Hawkes, H.E., and Webb, J.S., 1979, Geochemistry in mineral exploration: Academic Press, 657 p.
Schwartz, M.O. dan Surjono, 1990. The Stratabound deposit of Namsalu Kelapakampit, Indonesia. Econ. Geol. 95. 76-98.

Soepriadi dan Abidin, H.Z., 2014, Laporan Penyelidikan Untuk Menentukan Wilayah Pengeboran Eksplorasi Mineral Logam Timah Primer Dan Logam Lainnya, Daerah Parit Tebu dan Lintang, Kecamatan Gantung, Kabupaten Belitung Timur, Provinsi Kepulauan Bangka Belitung, Pusat Sumber Daya Geologi, Badan Geologi Bandung.

Soepriadi dan Bambang. P., 2015, Laporan Penelitian dan Evaluasi Hasil Pengeboran Logam Timah Primer di Daerah Parit Tebu, Kecamatan Gantung, Kabupaten Belitung Timur, Provinsi Kepulauan Bangka Belitung, Pusat Sumber Daya Geologi, Badan Geologi, Bandung.

Whitten, D.G.H., and Brooks, J.R.V., 1072, Dictionary of Geology, Penguin Books Ltd., London.

\begin{tabular}{|ll|}
\hline Diterima & $:$ 6 Juni 2016 \\
Direvisi & $:$ 18 Juli 2016 \\
Disetujui & $:$ 15 Agustus 2016 \\
\hline
\end{tabular}

